УДК 378.015.3:159.992:614.253.4

Вікторія ОСИПЕНКО, Оксана ПЕНДЕРЕЦЬКА,

ВДНЗ України «Буковинський державний

медичний університет»,

Чернівці (Україна)

\section{Victoria OSYPENKO,} Oksana PENDERETSKA,

Higher State Educational Establishment of

Ukraine «Bukovinian State Medical

University»,

Chernivtsi (Ukraine),

o_oviktoria@ukr.net,

mutiki@o2.pl
СОЦАЛЬНО-ПСИХОЛОГІЧНІ

ЧИННИКИ ФОРМУВАННЯ МОТИВАЦІї

ДО НАВЧАЛЬНОЇ ДІЯЛЬНОСТІ

МАЙБУТНІХ ЛІКАРІВ

SOCIAL AND PSYCHOLOGICAL

FACTORS IN THE FORMATION OF

MOTIVATION TO EDUCATION OF

FUTURE DOCTORS
Ключевые слова: мотив, мотивачия, цель, потребность, формирующие факторы, тип мотивации, уровень мотивации, положительная мотивация, негативная мотивация, положительное подкрепление, условия формирования позитивных мотивов, внутренняя мотивачия, познавательный интерес.
Осипенко В.А., Пендерецька О.М. Социальнопсихологические факторы формирования мотивации к учебной деятельности будущих врачей

В статье произведен теоретико-методологический анализ существующих научных исследований, предложена систематизация литературных источников в проблематике «мотивации» и «мотивов» к учебной деятельности. Проанализированы факторы, формирующие позитивную мотивацию, а также «цели» и «потребности» к овладению знаниями, навыками и умениями во врачебной профессии. Определены условия, влияющие на формирование позитивних мотивов учебно-познавательной деятельности студентов, а также методы, которые стимулируют учебно-познавательную деятельность: методы формирования познавательного интереса студентов и методы стимулирования их ответственности в учебе. Рассмотрены уровни учебной мотивации и призведена корелляция между процесса миадаптации студентов к условиям учебы в университете и формированием (изменением, под. влиянием внешних факторов) учебной мотивации. Указана значимость и необходимость позитивной мотивации к учебной деятельности будущего врача, как неотъемлемого элемента профессионального развития.
Актуальність теми дослідження. Значні зміни в сучасному українському суспільстві, що відбуваються внаслідок його трансформації, максимально актуалізують роль і значення соціально-психологічних факторів діяльності людини. Натомість, однією з актуальних задач, що стоять перед сучасною вищою школою, $є$ формування професіонала, готового відповідати постійно зростаючим вимогам ринку праці. Формування у студентів позитивної мотивації до майбутньої професії є тим фактором, який забезпечує конкурентоспроможність нашої країни на світовому рівні та підвищує якість підготовки майбутніх медичних фахівців. Проблема формування мотивів до навчання, що $\epsilon$ невід'ємним елементом у майбутньому професійному розвитку, є актуальним тому, що сучасні студенти поступово втрачають стимул до навчальної діяльності.

Мета та завдання дослідження полягає у теоретико-методологічному аналізі наявних 
наукових досліджень та систематизації літературних джерел щодо мотивації до навчальної діяльності з метою проведення в подальшому емпіричного дослідження та оптимізації мотивації студентів Вищого державного навчального закладу України» Буковинський державний медичний університет»

Ступінь наукової розробки. Загальнотеоретичні положеннях навчальної мотивації, розроблені у працях В. Давидова, О. Власової, Д.Ельконіна, Г. Костюка, О. Леонтьєва, С.Максименка, С.Рубінштейна, Є.Ільїна. Становлення і розвиток навчальної мотивації вивчалося М.Алексєєвою, Л. Божович, С.Занюком, Ю.Орловим, П. Якобсоном. Проблемі мотиваційної готовності першокурсників до навчання у вищому навчальному закладі присвячені наукові розвідки Л.Алімської, Л.Белясвої, Г.Бокарьової, А.Громцевої, М.Капельович, В.Раутен, О.Щеликової та ін. У науковому доробку психологів Е.Вальтеран, Н.Зенкової, І.Нестерової, М.Силкової розкривається психологічна готовність студентів до навчальної діяльності та до набуття знань, навичок і вмінь. Питання мотивації діяльності студентів у процесі навчання у вищому навчальному закладі при застосуванні різних навчальних завдань досліджують В.Білоус, Л.Горюнова, С.Занюк, В.Козаков, О.Коваленко, Л.Орбан-Лембрик, А.Цимбалюк і С.Цимбалюк, Є. Шматков та ін.

Для визначення ефективності процесу формування позитивної навчальної мотивації студентів важливими є праці М. Алексєєвої, Ю.Бабанського, В.Богословського, Л.Василенко, А.Виноградової, В.Галузяка, В.Давидова, Д.Ельконіна, М.Заброцького, А.Маркової, Т.Матись, М.Мільмана, В.Оконя, А.Орлова, О.Савонько, М.Савчина, М.Сметанського, А. Степанова, 3. Хізроєвої, В.Шахова та інших.

Всебічне вивчення причин поведінки людини корелюється 3 аналізом іiі потреб, мотивів, які спричиняють конкретні вчинки, поведінку загалом і все це разом характеризує мотивацію. Розглянемо детальніше такі поняття, як «потреба», «мотив» і «мотивація», які допоможуть нам проаналізувати роль та чинники мотивації студентів до навчальної діяльності.

Потреба - стан індивіда, пов'язаний 3 відчуттям необхідності в чомусь важливому для існування й розвитку людини ${ }^{1}$. Потреби $€$ джерелом активності людини, завдяки їм здійснюється регулювання ii поведінки, визначається спрямованість мислення, емоцій, почуттів і волі. Можливі варіанти для досягнення цілей, що забезпечують задоволення потреб, обираються на основі мотивів. Серед основних потреб особистості визначають: біологічні (потреби в їжі, повітрі тощо); матеріальні (потреба в предметно-суспільній діяльності, в усвідомленні свого місця в суспільстві); духовні (потреба в інформаційно-пізнавальній, моральній діяльності та ін.). Отже, ці потреби людини до тієї чи іншої діяльності виступають основою мотивів.

Мотиви, у свою чергу, складають основу мотивації індивіда до тієї чи іншої діяльності та зумовлюють його поведінку ${ }^{2}$. За концепцією М. Рогова,виокремлюються два великих блоки: безпосередні та опосередковані мотиви. Безпосередні мотиви включаються в сам процес діяльності і відповідають її соціально значущим цілям і цінностям; опосередковані ж пов'язані з цінностями, що не належать до самої діяльності, але хоча б частково в ній задовольняються. До безпосередніх мотивів належать: пізнавальні (прагнення творчої дослідницької діяльності, процес вирішення задач, самоосвіта, орієнтація на нові знання) та мотиви розвитку особистості (необхідність постійного інтелектуального та духовного зростання, прагнення бути ерудованим, підвищити свій загальнокультурний рівень). В структурі опосередкованих мотивів розрізняють: соціальні (усвідомлення необхідності вищої освіти; престижність вищої освіти; бажання стати повноцінним членом суспільства, обов'язок та відповідальність; соціальна ідентифікація; певний статус в групі; схвалення викладачів) і мотиви досягнення (краще підготуватися до професійної діяльності та отримати роботу, що гарно оплачується) $)^{3}$. Безперечно, навчально-пізнавальна діяльність студентів завжди є полімотивованою, тобто в структурі їх навчальних мотивів поєднуються зовнішні та внутрішні мотиви. До зовнішніх мотивів відносять прагнення отримати певний розвиток в навчанні, набуття нових знань, навичок і умінь, взаємодія 3 іншими студентами. Хоча також можуть мати місце й нейтральні, а іноді й негативні зовнішні мотиви. Наприклад, навчання як вимушена поведінка, навчання як намагання бути лідером або отримати престиж, прагнення бути в центрі уваги, бажання отримати тільки заохочення ${ }^{4}$.

Отже, поняття «мотив» являе собою досить складний феномен, якому науковці не дають однозначного визначення. В перекладі 3 латинської поняття «мотив» означає «ру- 
хаю». Мотив (Є.Ільїн) - це складне психологічне утворення, що спонукає до свідомих дій та вчинків, а також $є$ основою для цих дій. Поняттям «мотив» часто позначаються такі психологічні явища: намір, бажання, прагнення, побоювання тощо, у яких відображається наявність у людській психіці готовності, що спонукає до досягнення певної мети 5 .

На наш погляд, найбільш вдале визначення терміну «мотив» - це предметна потреба, тобто прагнення, бажання володіти чимось конкретним (дипломом вищої освіти, професією, іноземною мовою тощо). Непредметна потреба ще не є мотивом, оскільки не визначає характеру діяльності, тому що не має предмета, на який спрямована дія. Предмет, у свою чергу, окреслюється лише тоді, коли людина починає діяти.

Термін «мотивація» є набагато ширше, ніж термін «мотив» та інтерпретується як система мотивів або стимулів, чинників, що детермінують конкретну діяльність, поведінку особистості.

Слід, також розрізняти поняття «мотив» $\mathrm{i}$ «мета». Мета - це можливий, передбачуваний результат, який визначає й усвідомлює людина. Мотив - спонукання до досягнення мети.

У свідомості студента, безсумнівно, існують й інші мотиви (отримати гарні оцінки, виконати свої зобов'язання, отримати схвалення 3 боку викладачів та одногрупників тощо), але це тільки ті мотиви, які є зрозумілими й не для всіх вони є психологічно дієвими, особливо, якщо це стосується виконання не дуже «привабливого» завдання (не стійка, незріла мотивація до навчання). Тоді буває так, що в результаті задоволення цього мотиву (виконаннязавдання) студент отримуючи гарні оцінки (схвалення, підтримку тощо - позитивне підкріплення), в подальшому 3 меншими зусиллями виконуватиме домашні завдання. 3'являється новий дієвий мотив зробити завдання, щоб отримати визнання, схвалення та підтримку.

Значення для майбутнього медичного працівника того чи іншого мотиву залежить від багатьох чинників: віку студента, рівня його вихованості, розумових здібностей та інтелектуального розвитку, суспільних, соціальних умов, у яких проходить навчання, від оточення, професійної майстерності викладача, соціальної перспективи навчання. Лише за умов реалізації достатньої мотивації навчальної діяльності можна отримати позитивні результати.
Одне з основних завдань практичної психології на сьогодні, як зауважують дослідники, $є$ підготовка молоді до професійного самовдосконалення, формування інтересу до поступового оновлення знань. Це неможливо без стійкої мотивації до навчально-пізнавальної діяльності, що пов'язана 3 майбутньою професією.

Навчальна мотивація - це процес, який запускає, спрямовує й підтримує зусилля, що спрямовані на виконання навчальної діяльності. Це складна, комплексна система, що утворюється мотивами, цілями, реакціями на невдачу, цілеспрямованістю та установками студента.

Виокремлюють декілька типів мотивації, пов'язаної 3 результатами навчання: мотивація, яку умовно можна назвати негативною. Під негативною мотивацією розуміють такі спонукання студента, які викликані усвідомленням певних незручностей і невдач, які можуть виникнути, якщо він не буде навчатись (докори з боку батьків, викладачів, одногрупників тощо); позитивна мотивація, яка виявляється у двох формах (та, яка пов'язана $з$ результатом навчання й та, що пов'язана із метою навчання). Безумовно, деякі студенти мають позитивну мотивацію до навчання вже на 1 курсі - вони свідомо обрали свою майбутню професію і готові отримувати нові знання як для свого професійного майбутнього, так і для особистісного зростання.

Але, згідно даних, отриманих у результаті численних опитувань, більша частина студентської молоді, вступаючи до ВНЗ, не має готовності отримувати нові знання, і як наслідок - має низьку мотивацію до навчання, або взагалі не має мотивації до навчання.

Проаналізувавши дані, отримані науковцями, можна зробити висновок, що тільки 47\% абітурієнтів мають мотив - оволодіння професією, мотиви решти абітурієнтів - легкість, $з$ їх точки зору, вступу до ВМНЗ, можливість спілкування 3 однолітками, необхідність мати час для самовизначення, престижність диплома вищої освіти (саме диплому, а не освіти) ${ }^{6}$.

Певним чином про навчальну мотивацію свідчить рівень реальної успішності навчальної діяльності. До неї належать показники академічної успішності, відвідування й головне - показники сформованості навчальної діяльності студентів. В процесі навчання тип мотивації змінюється. На це впливають різноманітні чинники. Формування мотивації можливе лише тоді, коли людині вдається 
пов'язати мету з особистісними цінностями. Чим більш особистісні цінності пов'язані 3 результатом майбутньої діяльності, тим більше внутрішні мотиви підживлюватимуть енергію мотивації особистості.

Пізнавальний інтерес - сильний внутрішній мотив і як мотив навчання має безкорисливий характер.

Кожного студента можна оцінити за показниками його ставлення до навчання і за тим, якими $є$ його власні цілі та плани. Високий рівень мотивації навчання необхідний для досягнення успіху в навчанні і в цьому внесок мотивації в загальну успішність навчальної діяльності студента можна розгляддати на рівні когнітивних здібностей. Іноді менш здібний студент, але той, що має високий рівень мотивації до навчання може досягнути більш високих результатів в навчанні, тому що прагне до цього і приділяє навчанню більше часу та уваги. В той самий час у недостатньо вмотивованого студента успіхи у навчанні можуть бути незначними, навіть, не дивлячись на його здібності.

Всього виділяють 5 рівнів навчальної мотивації: висока, зовнішня, низька, негативне ставлення до навчання-дезадаптація.

3 цього випливає, що викладач має постійно відтворювати умови, при яких виникає потреба вчитися. Отже, досягненню позитивних результатів у підготовці висококваліфікованих фахівців сприяє використання активних методів особистісно-орієнтованого навчання, які дозволяють формувати знання, уміння і навички студентів шляхом залучення їх до активної навчально-пізнавальної діяльності, в результаті чого навчальна інформація переходить в особистісний досвід студентів.

Висновки. На основі результатів теоретико-методологічного аналізу наявних наукових досліджень та систематизації літературних джерел щодо мотивації до начальної діяльності термін «мотивація» $\epsilon$ набагато ширше, ніж термін «мотив» та інтерпретується як система мотивів або стимулів, чинників, що детермінують конкретну діяльність, поведінку особистості. Це поняття охоплює мотиви, потреби, цілі, наміри, переживання тощо. Значення для майбутнього медичного працівника того чи іншого мотиву залежить від багатьох чинників: віку студента, розумових здібностей та інтелектуального розвитку, соціальних умов, у яких проходить навчання, від оточення, професійної майстер- ності викладача, соціальної перспективи навчання тощо.

Лише за умов реалізації достатньої мотивації навчальної діяльності самого студента, позитивного підкріплення зі сторони викладачів та підтримки зі сторони батьків можна отримати позитивні результати.Формування у студентів позитивної мотивації до май бутньої професії є тим фактором, який забезпечує якість підготовки майбутніх медичних фахівців. Проте, це неможливо без стійкої мотивації до навчально-пізнавальної діяльності, що пов'язана з майбутньою професією.

\section{REFERENCE:}

1 Markova A.K. Formirovanie motivatsii ucheniya, A.K.Markova, T.A.Matis, A.B.Orlov, Moscow, Prosveshenie, 1990, 138 s.

${ }^{2}$ Yakobson P. M. Psihologicheskie problemy motivatsii povedeniya cheloveka, P.M.Yakobson, Moscow : A. S. K., 2001, 64 s.

${ }^{3}$ Rogov M. Motivatsiya uchebnoy i kommercheskoy deyatel'nosti studentov, M. Rogov, Vysshee obrazovanie v Rossii, 1998, 4, S. 8995.

${ }^{4}$ Malinauskas R. K. Motivatsiya studentov raznykh periodovobucheniya, R. K. Malinauskas, Sotsiologicheskie issledovaniya, 2005, 2, S. 134-138.

${ }^{5}$ Il'in E. I. Motivatsiya i motivy, E. I. Il'in. - SPb : Piter, 2003, 512 s, S. 8.

${ }^{6}$ Malinka O. O. Psihologichni problemi motivatsiyi navchal'no-profesiynoyi diyal'nosti studentiv u suchasnikh umovakh, O. O. Malinka, [Elektronnij resurs]. - available at : www.psyh.kiev.ua.

Osypenko Victoria, Penderetska Oksana. SOCIAL AND PSYCHOLOGICAL FACTORS IN THE FORMATION OF MOTIVATION TO EDUCATION OF FUTURE DOCTORS

In the article the theoretical and methodological analysis of existing research have done. Authors proposed systematization of literary sources in the problems of «motivation» and «motivation» to educational activity. Analyzed the factors forming a positive motivation, in addition «goal» and «needs» to mastering the knowledge and skills in the medical profession. Conditions are determined that affect the formation of positive motivation of teaching and cognitive activity of students and methods that stimulate learning and 
cognitive activity: the methods of formation of informative interest of students and stimulation methods of students' responsibility.

Were investigated the levels of educational motivation and was made a correlation between the processes of students' adaptation to the conditions studying at the university and the formation (external factors) of educational motivation. The value for future medical employee of the motivation depends on many factors: age of the student, upbringing, mental abilities and intellectual development, social conditions, the environment, professional skills of the teacher. Indicated the importance and necessity of positivemotivation to educational activity ofthe future doctor, as an integral element of professional development.

Key words: motive, motivation, purpose, need, forming factors, the type of motivation, motivation, positive motivation and negative motivation, positive reinforcement, conditions of formation of positive motivation, internal motivation, cognitive interest.

Received 23-10-2015

Advance Acces Publischer: November 2015 